\title{
First records of xylophilous Basidiomycetes (Fungi) in Mondaí, Santa Catarina (Southern Brazil)
}

\author{
Marisa de Campos-Santana* \\ Clarice Loguercio-Leite \\ Laboratório de Micologia, Departamento de Botânica, Centro de Ciências Biológicas, Universidade Federal de Santa Catarina \\ CEP 88010-970, Florianópolis - SC, Brazil \\ *Author for correspondence \\ marisacampossantana@yahoo.com.br
}

\begin{abstract}
A taxonomic survey of xylophilous Basidiomycetes resulted in the identification of 21 species belonging to the families Boreostereaceae Jülich (1), Ganodermataceae Donk (2), Hymenochaetaceae Imazeki \& Toki (6), Meripilaceae Jülich (2), Podoscyphaceae Reid (1), Polyporaceae Fr.: Corda (8) and Schizophyllaceae Quél. (1). All species are new records for Mondaí.
\end{abstract}

Key words: taxonomy, Basidiomycota, mycodiversity

\section{Resumo}

Primeiras citações de Basidiomycetes (Fungi) xilófilos para Mondaí, Santa Catarina, Brasil. Um levantamento taxonômico de Basidiomycetes xilófilos resultou na identificação de 21 espécies pertencentes às famílias Boreostereaceae Jülich (1), Ganodermataceae Donk (2), Hymenochaetaceae Imazeki \& Toki (6), Meripilaceae Jülich (2), Podoscyphaceae Reid (1), Polyporaceae Fr.: Corda (8) e Schizophyllaceae Quél. (1). Todas as espécies são novas citações para Mondaí.

Unitermos: taxonomia, Basidiomycota, micodiversidade

\section{Introduction}

The diversity shown in the fungus kingdom is surprising for its immense distribution and association with organic and inorganic substracts. The Fungi comprise one of the largest groups of eukariota in terrestrial environments, after insects (Fröhlich and Hyde, 1999). But knowledge of the mycodiversity is still extraordinarily deficient and fragmentary, making inventory di- fficult due primarily to the insufficient number of researchers in this area (Müeller and Bills, 2004).

The most acceptable estimate was made by Hawksworth (2004) who considers the existence of more than 1.5 million fungal species, of which only 100.000 (7\%) of the fungi have been described. A major part of the unknown taxa is supposed to be found in tropical regions, where the diversity of fungi higher than 
in temperate areas (Piepenbring, 2007). The subject of this works is to expand the knowledge of the xylophilous Basidiomycetes.

\section{Materials and Methods}

Mondaí is located in the extreme west of the state of Santa Catarina (27 $06^{\prime \prime} 16^{\prime} \mathrm{S}$ and $\left.53^{\circ} 24^{\prime \prime} 07^{\prime} \mathrm{W}\right)$, southern Brazil, with a total land area of nearly $201 \mathrm{~km}^{2}$. The area was originally covered by Deciduous Seasonal Forest and the collections for this work were made in the remnants of these forest. Field trips were carried out between December/2005 and May/2007 at two locations in the Mondaí municipality: Linha Sanga Forte and Linha Uruguai, areas of six and seven acres, respectively. After collections, the basidiomata were taken to the Laboratório de Micologia (BOT/CCB/UFSC), where they were analyzed.

The basidiomata were studied macroscopically, including dimensions (size, length of tube and context), number of pores $/ \mathrm{mm}$, insertion in the substratum and color (Munsell, 1975). To study microscopic characteristics, the basidiomata were freehand sectioned and stained with $1 \%$ phloxine solution $+5 \%$ or $1 \% \mathrm{KOH}$ solution (Ryvarden, 1991) and Melzer's reagent (Singer, 1975). Subsequently, microscopic characteristics, such as hyphae (types), cystidia and cystidioles, basidioles, basidia and basidiospores were measured under the light microscope (20 structure /slide) using a micrometric ocular lens. Illustrations were made with a camera lucida connected to the microscope. Data were compared with materials from FLOR, PACA, O, SP and ICN herbaria (Holmgren et al., 1990). Taxonomic arrangement followed Kirk et al. (2001).

\section{Results and Discussion}

This article provides keys to the identification of some taxa together with their geographical distribution in Brazil, comments, voucher material and illustrations of basidiospores (Figure 1) from each species.
AGARICALES Clem., 1909.

SCHIZOPHYLLACEAE Quél., 1888.

Schizophyllum commune (Fr.) Fr.

Systema Mycologicum 1: 330, 1821.

$\equiv$ Schyzophyllus communis Fr.,

Obs. Mycol. 1: 103, 1815.

Description in Cooke (1961).

Distribution: cosmopolitan, Brazil (AL, AP, PA, PB, PE, RN, RO, RS, SC, SP).

Voucher material: Brazil, Santa Catarina, Mondaí, Linha Uruguai, Campos-Santana \& Santana 222, 23/ V/2007 (FLOR).

Comments: This species is distinguished by whitish to buff color split lamellae; greyish or brownish, hirsute pilear surface with adhymenial hairs and thick context (Cooke, 1961), that make it easily recognizable in the field.

HYMENOCHAETALES Oberw., 1977.

HYMENOCHAETACEAE Imazeki \& Toki, 1954.

\section{Key}

1. Hyphal system monomitic..................................... 2

1'. Hyphal system dimitic..............................................

2 . Basidiomata resupinate, $2-3$ pores per $\mathrm{mm}$, spores 6-8 (9) $\times 4-5(7) \mu \mathrm{m}$, basidia $18-20 \times 6-7 \mu \mathrm{m}$

Inonotus $\mathrm{sp}$

2'. Basidiomata pileate sessile, spores measuring 5-7 $\times 3-4 \mu \mathrm{m}$, basidia $12 \times 5 \mu \mathrm{m}$, pores $3-5$ per $\mathrm{mm}$.

Inonotus patouillardii

3 . Presence of hymenial setae .4

3'. Absence of hymenial setae......................................5

4 . Hymenial setae, $20-30 \times 3-5 \mu \mathrm{m}$, spores $5.5-7 \times$ 5-6 $\mu \mathrm{m}$, ovoid to subglobose, golden-yellow to rusty brown.... Phellinus linteus 4'. Hymenial setae, $23-27 \times 5-6 \mu \mathrm{m}$, spores 3-4 $\times 2$ $3 \mu \mathrm{m}$, ellipsoid to ovoid, hyaline...... Fuscoporia gilva 5 . Spores dextrinoid, cystidioid elements present ....... Phellinus punctatus 5'. Spores non-dextrinoid, cystidioid elements absent Phellinus grenadensis 
Inonotus sp.

Voucher material: Brazil, Santa Catarina, Mondaí, Linha Sanga Forte, Campos-Santana \& Santana 288, 25/V/2007 (FLOR).

Comments: The specimens agree with Inonotus Karsten's genera concept. However, the macrocospic and microscopical characteristics were not the same as previously described species available in literature, and it will be necessary to expand research on this taxon.

\section{Inonotus patouillardii (Rick) Imazeki}

\section{Bulletin of the Tokyo Science Museum 6:} $105,1943$.

$\equiv$ Polystictus patouillardii Rick., Brotéria Bot. 6: 89., 1907.

Description in Ryvarden (2005).

Distribution: pantropical, Brazil (RS, SC).

Voucher material: Brazil, Santa Catarina, Mondaí, Linha Sanga Forte, Campos-Santana \& Santana 66, 14/ IV/2006 (FLOR).

Comments: The hard, lustrous context and large conspicuous setal hyphae are diagnostic characteristics for Inonotus patouillardii. The hymenial setae do not appear frequently (Loguercio-Leite, 1990).

Fuscoporia gilva (Schw.: Fr.) T. Wagner et \& M. Fischer

Mycologia 94: 1013, 2002.

$\equiv$ Boletus gilvus Schw., Schrift Nat Ges Leipzig 1:96, 1822.

Description in Ryvarden (2004).

Distribution: pantropical, Brazil (AL, AP, BA, MT, PA, PB, PE, PR, RS, RR, SC, SE, SP).

Voucher material: Brazil, Santa Catarina, Mondaí, Linha Sanga Forte, Campos-Santana \& Santana 55, 15/ IV/ 06 (FLOR).

Comments: Fuscoporia gilva (= Phellinus gilvus (Schwein) Pat.) is a very conspicuous species frequently collected in the tropics in open areas (Ryvarden, 2004). Macroscopically, it is similar to the species of Inonotus Karst. because of its annual and small basi- diomata. This species is characterized by its abundant ventricose hymenial setae and small ellipsoid basidiospores.

Phellinus grenadensis (Murril) Ryvarden

Norw. J. Bot. 18: 234, 1972.

EPyropolyporus grenadensis Murrill, North

Amer. Flora. 9: 107, 1908.

Description in Larsen and Cobb-Poulle (1990).

Distribution: pantropical, Brazil (BA, PB, PR, $\mathrm{RN}, \mathrm{RS}, \mathrm{SC})$.

Voucher material: Brazil, Santa Catarina, Mondaí, Linha Uruguai, Campos-Santana \& Santana 239, 23/ V/06 (FLOR).

Comments: The specimens are characterized at first by a fine velvety to tomentose rusty pilear surface, which become thick dark bay to black crustose ofter exposure, as well as showing distinct stratified tubes; without hymenial setae, thicker hyphae in the context and broadly elliptical to subglobose spores (Ryvarden, 2004).

Phellinus linteus (Berk. \& M. A. Curtis) Teng. Fungi of China :467, 1964.

$\equiv$ Polyporus linteus Berk. \& M. A. Curtis, Proc. Amer. Acad. Arts (Boston) 4: 122, 1860.

Description in Ryvarden (2004).

Distribution: pantropical, Brazil (SC).

Voucher material: Brazil, Santa Catarina, Mondaí, Linha Sanga Forte, Campos-Santana, Santana \& Zanella 123, 16/VI/06 (FLOR).

Comments: Diagnostic characteristics of this species are the pale golden brown spores, ovoid to subglobose spores and variably abundant setae (Ryvarden 2004). This species was previously recorded for Salto Veloso and Major Gercino, Santa Catarina, Brazil (Groposo et al., 2007).

Phellinus punctatus (Fr. ex P. Karst.) Pilát

Atlas Hub Europskych: 3 : 530, 1942.

EPolyporus punctatus Fr., Hymenomycetes

Europaei: 572, 1874. 
Description in Ryvarden (2004).

Distribution: cosmopolitan, Brazil (AP, PR, SC).

Voucher material: Brazil, Santa Catarina, Mondaí, Linha Sanga Forte, Campos-Santana \& Santana 292, 25/V/2007 (FLOR).

Comments: This species is recognizable in the field by the thick resupinate basidiomata that are often distinctly stratified; usually, it presents large globose dextrinoid spores, hyaline cystidioid elements and absence of setae.

POLYPORALES Gäum., 1926. BOREOSTEREACEAE Jülich,1982. Mycobonia flava (Fr.) Pat.

Bull. Soc. Myc. Fr. 10: 77, 1894.

EHirneola flava Fr. Syst. Orb. Veg.: 93, 1825.

Description in Reid (1976).

Distribution: neotropical, Brazil (MG, RS, SC).

Voucher material: Brazil, Santa Catarina, Mondaí, Linha Uruguai, Campos-Santana, Santana \& SouzaRodrigues 188, 27/XII/06 (FLOR).

Comments: Some authors consider this species to be different from Mycobonia brunneoleuca (Berk. \& M. A. Curtis) Pat. because its fusoid-ellipsoid basidiospores are smaller in width. The hyphal pegs at the hymenium, with subhymenial origin, are similar to those described by Corner (1984) and Reid (1976).

GANODERMATACEAE (Donk) Donk, 1948.

\section{Key}

1. Basidiomata pileate sessile, anamixodermic cutis ....... G. australe

1'. Basidiomata centrally or laterally stipitate, hymeniodermic cutis. G. lucidum

Ganoderma australe (Fr.) Pat.

Bull. Soc. Mycol. France. 5: 67, 1889.

$\equiv$ Polyporus australe Fr., Elench. Fung. $1: 108,1828$.

Description in Ryvarden (2004).
Distribution: pantropical, Brazil (BA, PR, RS, $\mathrm{SC})$.

Voucher material: Brazil, Santa Catarina, Mondaí, Linha Sanga Forte, Campos-Santana, Santana \& Souza-Rodrigues 25, 03/I/06 (FLOR).

Comments: This species is usually recognized due to its distinct black crust and dark brown pileus, tubes and context, as well as a dark line under its cutis. The cutis is anamixodermic, characteristic of what separates the species G. australe from G. applanatum (Pers.) Pat., which has a trichodermic cutis (LoguercioLeite et al., 2005).

Ganoderma lucidum (Curtis: Fr.) P. Karst.

Rer. Mycol. 3: 17.1881.

$\equiv$ Polyporus lucidus W. Curtis: Fr. Syst. Mycol. 1: 353, 1821.

Description in Gilbertson and Ryvarden (1986).

Distribution: cosmopolitan, Brazil (RS, SC).

Voucher material: Brazil, Santa Catarina, Mondaí, Linha Uruguai, Campos-Santana, Santana \& Zanella 138, 17/VI/06 (FLOR).

Comments: This species is very close to G. resinaceum Boudier, according to Gilbertson and Ryvarden (1986), who emphasize that G. lucidum (Curtis: Fr) P. Karst. is distinguished by its characteristically stipitate basidiomata, its hymeniodermic cutis and the size of its spores (globose and smaller than the ones in G. resinaceum Boudier).

MERIPILACEAE Jülich, 1982.

\section{Key}

1. Basidiomata pileate sessile, hymenophore orange, pores round to irregular, 3-6 per mm, spores subglobose to globose, $5-6 \times 5-7 \mu \mathrm{m}$. R. ulmarius

1 '. Basidiomata pileate stipitate, hymenophore cream, pores round to irregular, 8-14 per mm, spores ellipsoid to dropshaped, $4-5 \times 3-4 \mu \mathrm{m}$. R. amazonicus

Rigidoporus ulmarius (Sowerby ex. Fr.) Imazeki

Bull. Gout. Exp. Sta. Meguro 57: 119. 1952.

$\equiv$ Polyporus ulmarius Sowerby ex. Fr., Syst. Mycol. 1: 365. 1821. 
Description in Ryvarden and Johansen (1980). SP).

Distribution: cosmopolitan, Brazil (PR, RS, SC,

Voucher material: Brazil, Santa Catarina, Mondaí, Linha Uruguai, Campos-Santana \& Santana 222, 23/ V/2007 (FLOR).

Comments: Ryvarden and Johansen (1980) pointed out that this species has yellow to brownish yellow basidiomata of large size, globose to subglobose spores, and large and mammiform cystidioles among the basidia.

\section{Rigidoporus amazonicus Ryvarden}

Mycotaxon 28 (2): 537. 1987.

Description in Ryvarden (1987).

Distribution: Brazil (AM, SC).

Voucher material: Brazil, Santa Catarina, Mondaí, Linha Uruguai, Campos-Santana \& Santana 274, 25/ V/2007 (FLOR).

Comments: When Ryvarden (1987) described $R$. amazonicus as a new species, he emphasized that it seemed to be a large specimen of Rigidoporus biokoensis (Lloyd) Ryvarden, which also has a lateral stipe. However, $R$. biokoensis is a smaller species and besides that it has a homogeneous context and bigger globose spores.

PODOSCYPHACEAE Reid, 1965.

Cymatoderma caperatum (Berkeley \& Montagne) Reid

Kew Bulletin 10: 635, 1956.

$\equiv$ Thelephora caperata Berkeley \& Montagne,

Annls Sci. nat. Bot. 11: 241. 1849.

Description in Reid (1965).

Distribution: neotropical, Brazil (BA, MG, RS, SC, SP).

Voucher material: Brazil, Santa Catarina, Mondaí, Linha Uruguai, Campos-Santana, Santana \& SouzaRodrigues 202, 27/VII/06 (FLOR).

Comments: This species has a well developed thick cuticular zone, similar in struture to Cymatoderma blumei (Lév.) Reid. The differentiation between these two species is the absence of cystidia and spore size, larger in C. caperatum (Reid, 1965).

POLYPORACEAE Fr.: ex Corda, 1839.

\section{Key}

1. Spores and hyphae dextrinoid. Perenniporia martii

1 '. Spores and/or hyphae indextrinoid. . .2

2. Basidiomata pileate stipitate, hymenophore lamellate Stiptophyllum erubescens

2'. Basidiomata pileate sessile, ressupinate to effused-reflexed, poroid.

3. Presence of long black hairs in the pileus surface and basidiomata darkening in $\mathrm{KOH}$........................................ Hexagonia hydnoides

3'. Absence of long black hairs in the pileus surface and basidiomata

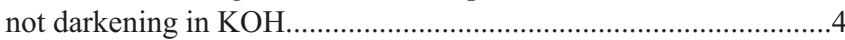

4. Basidiomata ressupinate to effuse- reflexed, hyphal system dimitic..................................................... Trichaptum byssogenum

4'. Basidiomata pileate sessile, hyphal system trimitic....................5

5. Context homogeneous, red-light to red-orange

Pycnoporus sanguineus

5'. Context duplex, with other colors. ....6 6

6 . Hymenial surface poroid, pores regular, hexagonal, abhymenial surface velutinous.

6'. Hymenial surface poroid and lamellate, pores irregular, partly sinuous-daedaloid and radially split, partly lamellate, abhymenial surface villose to glabrous. Trametes elegans

7. Basidiomata very thin, $0.2 \mathrm{~cm}$ thick, tubes up to $0.15 \mathrm{~cm}$ deep; spores 5-7 × 3-4 $\mu \mathrm{m}$........................................... Trametes villosa

7'. Basidiomata rather thick, $0.9 \mathrm{~cm}$ thick; tubes up to $0.4 \mathrm{~cm}$ deep; spores $5-7 \times 2-3 \mu \mathrm{m}$. Trametes socotrana

Hexagonia hydnoides (Swartz) M. Fidalgo

Mem. New York Bot. Gard. 17 : 64, 1968.

$\equiv$ Boletus hydnoides Kwartz, Fl. Ind. Occid.

3: 1942, 1806.

Description in Gilbertson and Ryvarden (1986).

Distribution: pantropical, Brazil (AL, AM, BA, ES, MG, PA, PB, PE, PR, RN, SC, SE, SP).

Voucher material: Brazil, Santa Catarina, Mondaí, Linha Sanga Forte, Campos-Santana, Santana \& Souza-Rodrigues 02, 03/I/ 06 (FLOR).

Comments: The upper dark brown to almost black pilear surface, densely covered with long dark branched hairs, and the small spores are both diagnostic characteristics of this species (Loguercio-Leite, 1994), besides flesh darkening in $\mathrm{KOH}$. 
Perenniporia martii (Berk) Ryvarden

Norw. J. Bot. 19: 143. 1972.

$\equiv$ Polyporus martius Berk., Hook. J. Bot. 8: 198. 1956.

Description in Ryvarden and Johansen, 1980.

Distribution: pantropical, Brazil (AM, BA, PR, RS, SC).

Voucher material: Brazil, Santa Catarina, Mondaí, Linha Uruguai, Campos-Santana \& Santana 245, 23/ V/07 (FLOR).

Comments: This is a rare species that presents a wide tropical and subtropical distribution. It is microscopically distinct due to its pipshaped or tapering spores. The cystidia are more common in African and Asian specimens than in American specimens (Ryvarden and Johansen, 1980).

Pycnoporus sanguineus (L.: Fr.) Murril

Bull. Torrey Bot. Club. 31: 421, 1904.

$\equiv$ Boletus sanguineus L., Species Pl. 2: 1646, 1763.

Description in Nuñez and Ryvarden (2000).

Distribution: pantropical, Brazil (AL, AP, PA, PB, PR, PE, RJ, RN, RS, SC, SP).

Voucher material: Brazil, Santa Catarina, Mondaí, Linha Sanga Forte, Campos-Santana, Santana \& Souza-Rodrigues 32, 03/I/06 (FLOR).

Comments: Pycnoporus sanguineus resembles P. cinnabarinus (Jacq.) P. Karst., but differs by having a thinner basidiomata, and smaller spores and basidia (Gilbertson and Ryvarden, 1987). The species can be found in fallen trunks, especially in open sunny forest areas.

Stiptophyllum erubescens (Berk.) Ryvarden

Norweg. J. Bot. 20: 4, 1973.

$\equiv$ Daedalea erubescens Berk. Ann. Nat. Hist. 4: 292, 1840.

Description in Ryvarden (1973).

Distribution: neotropical, Brazil (AM, BA, GO, MG, PA, PB, PR, RJ, RS, SC).
Voucher material: Brazil, Santa Catarina, Mondaí, Linha Sanga Forte, Campos-Santana \& Santana 71, 14/IV/06 (FLOR).

Comments: Basidia and spores are present only in young basidiomata. However, in spite of the lack of spores and basidia in older specimens, the identification of this specimen is not in doubt. This species differs from Xerotinus Fr. by its trimitic hyphal system and from Gloeophyllum Karst. due to the presence of stipitate pileus and wood brown-rot (Wright and Deschamps, 1977).

Trametes elegans (Spreng.:Fr.) Fr.

Epicr. Syst. Mycol.:492, 1838.

$\equiv$ Daedalea elegans Spreng., Sv. Vet. Akad. Handl.: 51, 1820.

Description in Gilbertson and Ryvarden (1987).

Distribution: cosmopolitan, Brazil (PE, RO, SC, SP).

Voucher material: Brazil, Santa Catarina, Mondaí, Linha Sanga Forte, Campos-Santana, Santana \& Souza-Rodrigues 29, 03/I/06 (FLOR).

Comments: The main feature that characterizes this species is an irregular hymenophore, with narrow lamellae or sinuous pores (Gilbertson and Ryvarden, 1987).

Trametes villosa (Fr.) Kreisel

Ciencias Biol. Ser. 4, 16: 84, 1971.

$\equiv$ Polyporus villosus Fr., Sist. Mycol. 1: 344, 1821.

Description in Loguercio-Leite (1993).

Distribution: pantropical, Brazil (AP, BA, PR, RS, SC, SP).

Voucher material: Brazil, Santa Catarina, Mondaí, Linha Sanga Forte, Campos-Santana, Santana \& Souza-Rodrigues 03, 03/I/06 (FLOR).

Comments: This species is easily recognizable in the field for its very thin, coriaceous, hirsute and strongly concentrically zoned pilear surface, besides its large pores (1-3 per $\mathrm{mm}$ ). The thickness of the basidiomata distinguish it from Trametes versicolour (L.:Fr.) Pilát, a close species that has thicker basidiomata, pores that 
are often deep and smaller (3-5 per mm), and without black line between context and the tomentum (Loguercio-Leite 1993).

\section{Trametes versicolor Cooke}

Grevillea 11: 39, 1882.

Description in Loguercio-Leite (1993).

Distribution: pantropical, no Brazil (SC).

Voucher material: Brazil, Santa Catarina, Mondaí, Linha Sanga Forte, Campos-Santana, Santana \& Souza-Rodrigues 09, 03/I/06 (FLOR).

Comments: Loguercio-Leite (1993) stressed that this species is very similar to Trametes hirsuta (Wulf.: Fr.) Pil., but that it can be distinguished by the presence of cylindrical and thin spores and double context.

Trichaptum byssogenum (Jungh.) Ryvarden

Norwegian Journal of Botany 19: 237, 1972.

$\equiv$ Polyporus byssogenus Jungh., Verh. Batav. Genootsch. 17: 43, 1838.

Description in Nuñez and Ryvarden (2001).

Distribution: pantropical, Brazil (AM, BA, RO, SC, SP).

Voucher material: Brazil, Santa Catarina, Mondaí, Linha Sanga Forte, Campos-Santana, Santana \& Zanella 102, 16/VI/06 (FLOR).

Comments: It is easily recognizable in the field by its moderately coarse greyish to pale brownish tomentum and, flexible consistency (Gilbertson and Ryvarden, 1987).

The inventory of xylophilous Basidiomycetes, carried out at two locations in the Mondaí municipality (Linha Sanga Forte and Linha Uruguai) resulted in the identification of 21 species, all of which are new records. Polyporaceae was the best-represented family with eight species, followed by Hymenochaetaceae with six species. Most specimens collected belong to two species: Trametes villosa (Fr.) Kreisel (13) and Stiptophyllum erubescens (Berk.) Ryvarden (5), which is the only wood brown-rot species.
The current data demonstrates that it is necessary to continue with cumulative taxonomic efforts to reinforce the knowledge about mycodiversity, mainly in tropical areas. a

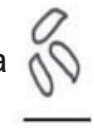

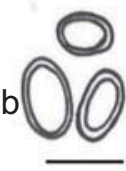

c
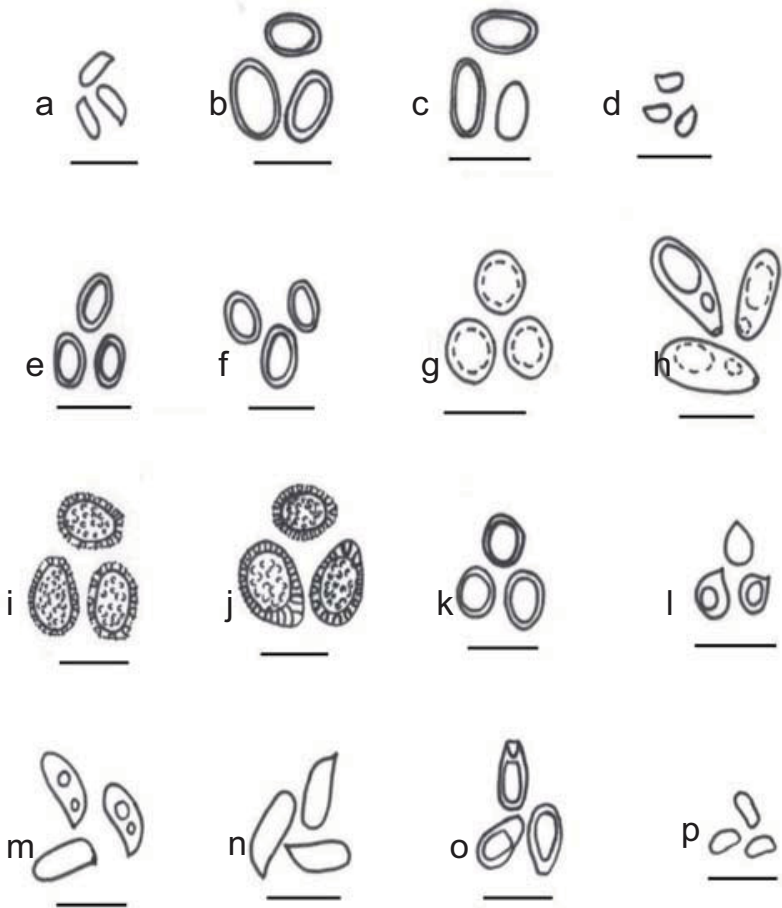
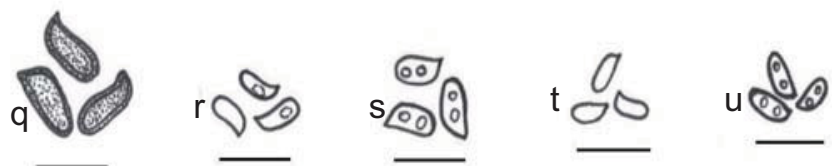

FIGURE 1: Spores of species a) Schizophyllum commune; b) Inonotus sp.; c) Inonotus patouillardii; d) Fuscoporia gilva; e) Phellinus grenadensis; f) Phellinus linteus; g) Phellinus punctatus; h) Mycobonia flava; i) Ganoderma australe; j) Ganoderma lucidum; k) Rigidoporus ulmarius l) Rigidoporus amazonicus; m) $C y$ matoderma caperatum; n) Hexagonia hydnoides; o) Perenniporia martius; p) Pycnoporus sanguineus; q) Stiptophyllum erubescens; r) Trametes elegans; s) Trametes villosa; t) Trametes socotrana; u) Trichaptum byssogenum. Scale $=10 \mu \mathrm{m}$.

\section{Acknowledgements}

The authors are grateful to Venceslau Santana, Reinaldo Rodrigues de Souza and Nina Zanella, especially for their help with the field work. This work is part of an M.Sc. thesis (PPGBVE Biologia Vegetal, BOT, CCB, Universidade Federal de Santa Catari- 
na, Brazil) of the first author. We are grateful to the reviewers and would like to express our deep thanks for their help in the correction and improvement of the present article.

\section{References}

Cooke, W. M. 1961. The Genus Schyzophyllum. Mycologia, 53 (6): 575-599.

Corner, E. J. H. 1984. Ad Polyporaceas II e III - Polyporus, Mycobonia, Echinochaete. Nova Hedwigia, 78: 1-127.

Frölich, J.; Hyde, K. D. 1999. Biodiversity of palm fungi in the tropics: Are global fungal diversity estimates realistic? Biodiversity and Conservation, 8: 977-1004.

Gilbertson, R. L.; Ryvarden, L. 1986. North American Polypores. Fungiflora, Oslo, Norway, 433pp.

Gilbertson, R. L.; Ryvarden, L. 1987. North American Polypores. Fungiflora, Oslo, Norway, 423pp.

Groposo, C.; Loguercio-Leite, C.; Góes-Neto. A. 2007. Fuscoporia (Basidiomycota, Hymenochaetales) in Southern Brazil. Mycotaxon, 101 (1): 55-63.

Hawksworth, D. L. 2004. Fungal diversity and its implications for genetic resource collections. Studies in Mycology, 50: 9-18.

Holmgren, P. K.; Holmgren, N. H.; Barnett, L. C. 1990. Index Herbariorum. Part 1. The Herbaria of the World. International Association for Plant Taxonomy, Botanical Garden, New York, New York, USA, 693pp.

Kirk, P. M.; Cannon, P. F.; David, J. C.; Stalpers, J. 2001. Ainsworth $\&$ Bisby's Dictionary of the Fungi. $9^{\text {th }}$ ed. Wallingford, CAB International, Oxon, USA, 655pp.

Larsen, M. J.; Cobb-Poulle, L. A. 1990. Phellinus (Hymenochaetaceae) - A survey of world taxa. Synopsis Fungorum, 3: 1-206.

Loguercio-Leite, C. 1990. Políporos (Basidiomycota) xilófilos de la Ilha de Santa Catarina, Santa Catarina, Brasil. Tese de Doutorado FCNE, UBA, Buenos Aires, Argentina, 208pp.

Loguercio-Leite, C. 1993. Polyporaceae II: Trametes Fr. na Ilha de Santa Catarina, SC, Brasil. Insula, 22: 3-20.

Loguercio-Leite, C. 1994. Polyporaceae na Ilha de Santa Catarina, III: o gênero Hexagonia Fr. Insula, 23: 3-14.

Loguercio-Leite, C.; Groposo, C.; Halmenchlager, M. A. 2005. Species of Ganoderma Karsten in subtropical area (Santa Catarina
State, Southern Brazil). Iheringia, Série Botânica, 60 (2): $135-$ 139.

Mueller, G. M.; Bills, G. 2004. Introduction. In: Mueller, G. M.; Bills, G. F. \& Foster, M. S. (eds.). Biodiversity of Fungi: Inventory and monitoring methods. Elsevier Academic Press, London, UK, p.1-4.

Munsell, L. 1975. Munsell soil colour charts. U. S. Dep. Agric. Hand 18 - Soil Survey Manual, Baltimore, USA, 16pp.

Nuñez, M.; Ryvarden, L. 2000. East Asian Polypores. Ganodermataceae and Hymenochaetaceae. Fungiflora, Oslo, Norway, $168 \mathrm{pp}$.

Nuñez, M.; Ryvarden, L. 2001. East Asian Polypores, Polyporaceae s. lato. Fungiflora, Oslo, Norway, 168pp.

Piepenbring, M. 2007. Inventory the fungi of Panama. Biodiversity Conservation, 16: 73-84.

Reid, A. D. 1965. A monograph of the stipitate stereoid fungi. Nova Hedwigia, 18:1-388.

Reid, C. G. 1976. Notes on Polypores. 2. Memoirs of the New York Botanical Garden, 26 (1): 179-198.

Ryvarden, L. 1973. New Genera in the Polyporaceae. Norwegian Journal of Botany, 20 (1): 1-5.

Ryvarden, L. 1987. New and noteworthy polypores from tropical America. Mycotaxon, 28 (2): 525-542.

Ryvarden, L. 1991. Genera of Polypores - Nomenclature and taxonomy. Synopsis Fungorum 5, Fungiflora, Oslo, Norway, 363pp.

Ryvarden, L. 2004. Neotropical Polypores Part 1. Introduction, Ganodermataceae \& Hymenochaetaceae. Synopsis Fungorum, 19: $1-229$.

Ryvarden, L. 2005. The genus Inonotus - a synopsis. Synopsis Fungorum, 21: 1-149.

Ryvarden, L.; Johansen, I. 1980. A preliminary polypore Flora of East Africa. Fungiflora, Oslo, Norway, 636pp.

Singer, R. 1975. The Agaricales in modern taxonomy. $3^{\text {th }}$ ed. Vaduz. J. Cramer, Stuttgart, Germany, 912pp.

Wright, J. E.; Deschamps, J. R. 1977. Basidiomicetos xilófilos de la Región INTA, s. 5, Mesopotámica III. Los Géneros Bjekandera, Gloeophyllum, Gloeoporus, Hirschioporus, Hydnopolyporus, Phaeocoriolellus, Pycnoporus y Xerotinus. Buenos Aires. Revista de Investigaciones Apropecuarias, 3 (2): 27-70. 